\title{
Life expectancy of daily newspapers in the Netherlands: the Period 1848 - 1997
}

Citation for published version (APA):

van Kranenburg, H. L., Palm, F. C., \& Pfann, G. A. (1998). Life expectancy of daily newspapers in the Netherlands: the Period 1848 - 1997. METEOR, Maastricht University School of Business and Economics. METEOR Research Memorandum No. 005 https://doi.org/10.26481/umamet.1998005

Document status and date:

Published: 01/01/1998

DOI:

10.26481/umamet.1998005

Document Version:

Publisher's PDF, also known as Version of record

\section{Please check the document version of this publication:}

- A submitted manuscript is the version of the article upon submission and before peer-review. There can be important differences between the submitted version and the official published version of record.

People interested in the research are advised to contact the author for the final version of the publication, or visit the DOI to the publisher's website.

- The final author version and the galley proof are versions of the publication after peer review.

- The final published version features the final layout of the paper including the volume, issue and page numbers.

Link to publication

\footnotetext{
General rights rights.

- You may freely distribute the URL identifying the publication in the public portal. please follow below link for the End User Agreement:

www.umlib.nl/taverne-license

Take down policy

If you believe that this document breaches copyright please contact us at:

repository@maastrichtuniversity.nl

providing details and we will investigate your claim.
}

Copyright and moral rights for the publications made accessible in the public portal are retained by the authors and/or other copyright owners and it is a condition of accessing publications that users recognise and abide by the legal requirements associated with these

- Users may download and print one copy of any publication from the public portal for the purpose of private study or research.

- You may not further distribute the material or use it for any profit-making activity or commercial gain

If the publication is distributed under the terms of Article $25 \mathrm{fa}$ of the Dutch Copyright Act, indicated by the "Taverne" license above, 
Life Expectancy of Daily Newspapers in the Netherlands: The Period 1848 - $1997^{1}$.

\author{
H.L. van Kranenburg \\ Department of Quantitative Economics, Maastricht University.
}

Franz C. Palm

Department of Quantitative Economics, Maastricht University.

\title{
Gerard A. Pfann
}

Business Investment Research Center, Maastricht University and C.E.P.R.

\section{October 1998}

ABSTRACT: In 1848 freedom of press was written into the Constitution of the Kingdom of the Netherlands. This paper investigates the expected life span of daily newspapers in the Netherlands since then. Life expectancy depends on the cyclical evolution of the number of daily newspapers through time. The life cycle of the competitive newspaper industry in the Netherlands is characterized by a turning period of turmoil during World War II. Models that aim at estimating the expected lifetime of newspaper that do not acknowledge the cyclical characteristics of the industry are most likely misspecified.

Keywords: Density, hazard function, product life cycle, newspapers.

JEL Code: $\quad 611,630$ 


\section{1. $\quad$ Introduction}

Freedom of the press was written in Article 7 of the Constitution of the Kingdom of the Netherlands in 1848. Until World War II the number of daily newspapers enlarged steadily. In 1869 an explosive increase occurred as a result of the abolishment of a special tax system for newspapers, known as the 'dagbladzegel' (cf. Hemels (1969a, b)). According to Schneider and Hemels (1979) this change caused a drop in production costs by as much as fifty percent, raising survival chances for existing newspapers and lowering entry costs for new publications. During the late sixties and early seventies the market for daily newspapers in the Netherlands is confronted with an upsurge in press concentration. As a temporary provision against concentration of the press in 1971 the Dutch government installs the 'Bedrijfsfonds voor de Pers' to financially support daily newspapers in trouble, which becomes a foundation in 1974 and still exists today.

This paper is the first of a series of papers to analyze the economic dynamics of the market for daily newspapers in the Netherlands using data on all daily newspapers in the Netherlands from 1848 until 1997. Modeling the dynamics of the Dutch daily newspaper market is inspired by its nature, characterized by an oligopolistic structure with a price inelastic demand and differentiated supply, being linguistically delimited and regionally segmented. Its history is well-documented while long time-series carrying newspaper specific statistical information are available.

Research on the newspaper market in the Netherlands has focussed primarily on the decreased number of newspaper titles during the last decades. De Ridder (1984) studies concentration tendencies over the period 1950 to 1982, using a sample of 33 daily newspapers. He finds that the number of newspapers reduces, widely circulating papers expand faster, and an increasing number of publishers unite or start working in close cooperation. Van Cuilenburg et al. (1988) argue that the inverse relationship between the number of daily newspapers in the 
market (press concentration) and the number of copies sold (circulation) is due to the increasing costs of productive capital. Indeed, the number of copies sold did increase at least until 1990 (see Abbring and Van Ours (1994)). However, according to Jovanovic and MacDonald (1994) life cycle theory of competitive industries and empirical evidence suggest that technological shocks and increasing production efficiency reduce production costs, giving rise to increasing the firm's (newspaper's) optimal scale (circulation). Klepper (1996) finds that during the declining phase of the industry life cycle firms with high product to process investment ratios are disproportionally driven out of the market due to production costs disadvantages.

The aim of this paper is to study the life cycle of the market for daily newspapers in the Netherlands. In particular we study the determinants of the life expectancy of daily newspapers over the period 1848 - 1997 using hazard rate models as in, for example, Audretsch and Mahmood (1995). Besides duration, market density measures, indicators for regional market segmentation and dummy variables for World War II are the main determinants of the survival rates of daily newspapers. We compare our findings with those of other studies such as Carroll (1987) and Carroll and Hannan (1995) who investigate the market for newspaper publishers in Argentina, Ireland and the U.S. for a longer period of time.

To the extent that the availability of data allows us to study the statistical regularities that have emerged from the empirical industrial organization literature we will do so. For instance, in his bound approach Sutton (1997) advocates to check these regularities in empirical studies. He mentions the following empirical regularities: (1) concerning size and growth: the probability of survival increases with firm size and the rate of growth of a firm given that it survives is decreasing in size, (2) regarding the life cycle: the rate of growth of a firm is smaller as the firm becomes older but the probability of survival is greater, (3) with respect to shakeout: the number of firms tends to rise to a peak and later to fall to some lower level, (4) on turbulence: across 
industries there is a positive correlation between gross entry rates and gross exit rates.

The 150 years of data available for this study is a long enough spell to observe an almost complete life cycle of the newspaper industry. We consider the effects of the life cycle phases on the expected life span of daily newspapers. Despite the long tradition of research investigating factors which determine whether a new business is likely to survive, Brüderl et al. (1992) come to the conclusion that the results are inconclusive. The reason being the inconsistent and sometimes incorrect use of various research methodologies in different studies. We estimate a Cox's proportional hazard model and several survivor functions to find out which model fits the data best.

The paper is organized as follows. Section 2 outlines the econometric models, and section 3 presents the data used in this study. In section 4 the outcomes of our empirical analysis are being discussed. Section 5 concludes.

\section{2: $\quad$ Event history and duration models}

Previous studies on the Dutch daily newspaper market did neither use all available historical data nor did they account for the life-cycle dependence when studying the market dynamics. Event history and duration models are most appropriate to investigate the relationship between daily newspaper survival rates and the evolution of the newspaper industry. The analysis of the number of titles and their circulation should include the state variables of the market for newspapers. Even in the case where complete spells of data are not available, at least the fact that the evolution of publication rates is state dependent must be acknowledged.

A natural starting point for such a study is the survivor function that a: is easy to understand, b: is practical to work with, and c: produces results which can be interpreted in a straightforward manner. An example of such a model is the survivor function that assumes an 
exponential distribution of duration (see Kiefer $(1985,1988)$ and Lancaster (1990)).

Let $\mathrm{F}(\mathrm{t})$ be the distribution function $\mathrm{F}(\mathrm{t})=\operatorname{Pr}(\mathrm{T}<\mathrm{t})$ of random variable $\mathrm{T}$ - being the lifetime on newspaper-specific clocks, that are set equal to zero at the moment a newspaper enters the market - is less than $\mathrm{t}$, and let $\mathrm{f}(\mathrm{t})=\mathrm{dF}(\mathrm{t}) / \mathrm{dt}$ be the unconditional probability density function. The survivor function is defined as $S(t)=1-F(t)=\operatorname{Prob}(T \geq t)$. The exponential distribution function is defined as

$\mathrm{F}(\mathrm{t})=1-\exp (-\lambda \mathrm{t}), \quad \lambda>0$

The ratio of the density and the survivor function, $f(t) / S(t)$, is referred to as the hazard rate, $h(t)$, which is "the rate at which spells will be completed at duration $\mathrm{t}$, given that they last until $\mathrm{t}$ " (op cit. Kiefer (1988), page 651). For the exponential distribution of durations, the hazard rate yields: $\mathrm{h}(\mathrm{t})=\lambda$, which is constant through time and therefore characterized as memoryless. This property is often found to be in conflict with data on duration dependence and alternative functions have been suggested. In this paper we also consider survival models that correspond with the Weibull and the Gamma distributions ${ }^{1}$, and with the Normal and Log-logistic distributions which do not imply monotonic exit rates. Duration dependence is positive if the hazard rate rises with $t$ $(\mathrm{dh}(\mathrm{t}) / \mathrm{dt}>0)$, meaning that the exit probability increases with the duration of being in the market. Vice versa, if $\mathrm{dh}(\mathrm{t}) / \mathrm{dt}<0$, duration dependence is negative, reducing the exit probability with age. Although duration functions and corresponding hazard rates relate to economic theory and appeal to the economist's intuition, neither theory nor intuition provide sufficient guidance

\footnotetext{
${ }^{1}$ Stacy \& Mihram's (1965) generalized Gamma distribution with p.d.f. for duration t yields $\mathrm{f}(\mathrm{t})=\rho \lambda^{\theta \rho} \mathrm{\rho}^{\theta-1} \exp \left[-(\lambda \mathrm{t})^{\rho}\right] / \Gamma(\theta)$, with $\Gamma($.) being the Gamma function. The three-parameter Weibull distribution is a special case if $\theta=1$; the exponential distribution is a special case if $\theta=1$ and $\rho=1$. The effects of explanatory variables $\mathrm{X}$ on the survival rate or the hazard function can be incorporated by substituting $\lambda=\exp (-\beta \mathrm{X})$.
} 
to decide a priori what an appropriate model may be. Apart from letting the data speak for themselves, a commonly applied solution in duration studies is the use of the proportional hazard function that depends on the baseline hazard rate $\mathrm{h}_{0}(\mathrm{t})$ multiplied by a vector of explanatory variables $\mathrm{X}$ with unknown coefficients $\beta$. This yields

$\mathrm{H}(\mathrm{t}, \mathrm{X}, \beta, \mathrm{h})=\exp (\beta \mathrm{X}) * \mathrm{~h}_{0}(\mathrm{t})$

with $h_{0}(t)$, the baseline hazard function being independent of $X$ and equal to $H($.$) if \beta=0$. The exogenous variables shift the level of the hazard rate, but do not affect its shape as a function of duration.

The partial-likelihood approach, initially suggested by Cox (1975), can be used to estimate $\beta$ independently of $h_{0}(t)$. The partial likelihood is the ratio of the hazard function $H($.$) for the$ single spell that is completed at duration $\mathrm{t}$, divided by the sum of spells which are still in progress at duration t. A major advantage of this approach is the easy handling of censored data, and the estimation of $\beta$ without knowledge on $\mathrm{h}_{0}(\mathrm{t})$. A shortcoming, however, is its inflexibility and the fact that the baseline and the intercept in $\exp (\beta X)$ cannot be jointly estimated with the coefficients of the exogenous variables. The proportional hazard function is homogeneous of degree zero in the vector of explanatory variables, so that any variable that does not vary over spells will simply multiply both numerator and denumerator of the partial likelihood function, and consequently drop out. Therefore, we do not only estimate Cox's proportional hazard function, but we also present estimates of the various survivor functions we have discussed being extended with explanatory variables $\mathrm{X}$.

\section{The data}


The unit of analysis in our research is the newspaper publication (title). Our data set contains information on every daily newspaper which appeared on the market that has left a historical record of its existence, and constitutes the complete historical product population of a single product market since 1848 . We concentrate on newspapers rather than publishing companies because each newspaper has its own market segment and clientele. In the early times, a publishing company could be identified by its newspaper, but in the beginning of the twentieth century companies started to publish more than one newspaper title. The characteristics of a newspaper determine the circulation and the clientele and not the publishing company. Nowadays, a newspaper is generally one of many products of the publishing company. These companies are not specialized in publishing newspapers only, but they have a vast range of multimedia products.

Our unit of research is defined as a daily newspaper if it satisfies five criteria. The selection requirements are composed from the criteria defined by Carroll (1987) and Emery and Emery (1978, p4). Newspapers must be available to anyone willing to pay the price, and they print anything of interest to a general public; their contents should consist of timely information. In most countries and especially in the early days newspapers are either nationally or locally oriented. Hence, those interested in a particular newspaper - advertisers, readers, suppliers - face a geographically and linguistically delimited market. We add an additional criterium: daily newspaper are (eventually) published 6 days per week. The criteria for a newspaper to be defined as a daily newspaper can thus be summarized as follows. Daily newspapers

1. follow a daily publishing scheme (6 days a week).

2. are available to anyone willing to pay the price, regardless of class or special interest.

3. publish selected material of interest to a general public, as contrasted with religious and/or business publications.

4. contents consist of timely information. 
5. published information is directed to a geographically and linguistically delimited market of consumers and advertisers.

For an adaquate analysis of the market evolution it is important to define precisely, when a unit ceases to exist, i.e. one of the first tasks in studying the death of a unit is defining when a newspaper disappears from the market. A unit's death occurs when a newspaper title does not persist in name anymore, and when it has lost its identity at the same time. Losing the identity can be caused by several factors. A newspaper death occurs when a newspaper legally ceased to exist. Other causes of loosing the identity, like mergers or takeovers, are more complicated. Discussion of this question often depends on the opinion of the researcher. Literature dealing with mergers has shown that there is a continuum of outcomes to merger partners. Small newspapers may be absorbed and have virtually no further idiosyncratic existence. Or, at the other extreme, one newspaper absorbs another without bearing a significant impact on its own structure. The other structural forms of mergers lie within the range of the two extremes. We have characterized mergers as one of the three types (see also Carroll (1987)): 1. the focal newspaper absorbs another newspaper with persisting its own title; 2. the focal newspaper is absorded without persisting its title; 3 . the focal newspaper merges with one or more newspaper publications and a new title results. The first type of merger is not death; the record of the focal newspaper continues unaltered. The second type, takeover, is characterized as the focal newspaper's death. The third type of merger is commonly treated as the creation of one new newspaper publication. However, our definition of this type of merger involves one surviving newspaper, while the others exit. The merit of our treatment is that the existing knowledge remains embodied in the market in the form of the one remaining newspaper, which seems more realistic than the creation of a brand new title without any historical relationships. This type of merger is known as horizontal mergers within the same industry (see also Dunne et al., (1988)). 
Economists focus on the costs that an entrant had to make to conquer a market share, fighting the goodwill the incumbents have created amongst their consumers. Potential entrants stimulate competition in the market. Tammeling (1988) illustrated this process with the foundation of 'De Nieuwe Drentsche Courant' in 1852. This newspaper existed only two years, but its appearance stimulated the competitive attitude of the 'Provinciale Drentsche en Asser Courant', its immediate rival. The incumbent newspaper publishing company responded by improving the quality of its paper. Its response became more aggressive eventually resulting in an aquisition of the new newspaper by the incumbent.

Despite the apparently high quality of the data, the nature of the effort surely resulted in some historical inaccuracies. Most likely, these involve omission of some small and short-lived newspapers. In total we have monitored 261 daily newspapers' appearances in the Netherlands since 1848. The data set contains sometimes very detailed information about the population of newspapers in the Netherlands. The construction of the data set used information from Goedhart (1943), Hemels (1969a, b), Overhof (1995), Schneider and Hemels (1979), Tammeling (1988), Ridder (1984), Ros (1993), Vermeulen (1994) and Witteloostuijn et al. (1996) and information obtained from the National Press Museum. For every newspaper in the data set the following information is available:

1. Censor: a dummy variable indicating right censored vs. uncensored cases ${ }^{2}$;

2. Spell: $\quad$ Length of the lifetime spell, measured as the difference between the year at which the newspaper ceased to appear and the year of initial publication;

3. Left: $\quad$ For left censored cases, the age at the start of our counting year;

2 Our data set is corrected for those which entered the market before our starting year; they are treated as uncensored cases. In order to avoid misinterpretation we corrected these cases by adding the variable age of a newspaper at the year 1848 . 
4. YearIn: Initial year of appearance of the daily newspaper;

5. YearOut: Year of disappearance from the market;

6. InWW2: A dummy variable indicating if a newspaper is forced to exit the market during World War II;

7. PastWW2: A dummy variable indicating if a newspaper enters the market in response to World War II in 1945-1946;

8. Dens $(j)$ : Number of newspaper titles one year before newspaper enters the market before $1946(\mathrm{j}=1)$ or after $1945(\mathrm{j}=2)$;

9. Region: Indicator for main regional appearance. The definition of the regions in our study is based on the classification that is published by the Dutch Central Bureau of Statistics. The four regions are composed from the twelve provinces:

North: $\quad$ Friesland, Groningen, and Drente;

East: $\quad$ Gelderland, Overijssel, and since 1986 Flevoland;

South: $\quad$ Noord-Brabant, and Limburg;

West: $\quad$ Utrecht, Zuid-Holland, Noord-Holland, and Zeeland ${ }^{3}$.

10. Found: Dummy variable indicating if a newspaper is founded after 1945;

11. Diff $(j)$ : Variable representing the development of the number of newspapers in the market. Diff $(\mathrm{j}=3)$ expresses the difference in numbers of newspapers between the year of exiting the market before 1946 and 1848. Diff $(\mathrm{j}=4)$ expresses the difference between 1945 and the year of exiting the market after $1945^{4}$.

${ }^{3}$ In spite of the fact that few newspapers have been nationally distributed after their first appearance, we have selected them in one of the four regions. The selection criterium was the region with the highest market share for that particular newspaper.

${ }^{4}$ When an observed duration of length $\mathrm{T}$ is incomplete, the observation for the lifetime of that newspaper contains only the information that duration is at least $\mathrm{T}$, given the state of exogenous variables at that time. Consequently, the contribution to the likelihood function is the probability that the newspaper publication has a 
Basically, we created variables as to distinguish in a crude way between two stages in the life cycle of the Dutch daily newspaper industry. The first stage is the phase in which the number of newspaper titles emerging in the market increases. The second stage is characterized by a diminishing number of newspapers in a market that becomes increasingly concentrated.

\section{4. $\quad$ Empirical results}

This paragraph is divided into two parts. First a descriptive analysis of the data is given. The second part is devoted to a discussion of the outcomes of the parameter estimates of the hazard and survivor functions.

\section{Descriptive analysis}

Newspapers which have appeared before the year 1848 had generally time and government support to establish a clientele. According to Schneider and Hemels (1979) these newspaper organizations were obliged to print the city or provincial weapon at the front of their newspapers to receive the support. Many newspapers, however, frequently faced capital and cash-flow problems very early on. They could be forced by creditors to liquidate before they had the time to establish a clientele. The actual lifetime of the first-movers had been postponed until the time of their government independence. It is likely to assume that the newspaper market is dominated by the first-movers' advantage in the Netherlands. As of today 55 daily newspapers are published by 11 publishing companies, of which only four publish one daily newspaper. From

duration greater than T. Since some newspapers appear in both phases of the product life cycle, we assume that other determinants than $\operatorname{diff}(j=3,4)$ influence their survival chances. In other words, for these particular newspapers $\operatorname{diff}(\mathrm{j}=3,4)$ are set to 0 . The creation and application of a dynamic dataset will solve this problem. 
today's existing newspapers 9 have appeared for the first time before the year 1848, 21 between 1848-1900, 9 between 1900-1939, and 6 were established during World War II, and 10 after 1945. Table 4.1. summarizes the number of established daily newspapers in the Netherlands during specified time periods that still exist in 1997. This table also exhibits the total number of foundations of newspaper titles in the periods considered, and presents the correlations between the number of annually entering and exiting of daily newspapers. The correlations are, except during World War II, remarkably low compared to, for example, turnover of companies in the U.K. manufacturing industry. For 95 different industries Geroski (1991) finds a correlation of .796. Sutton's (1997) fourth regularity of turbulence - meant to apply to firms - applies only in a very limited sense to the products in the Netherlands market of daily newspapers.

\section{[INSERT TABLE 4.1 ABOUT HERE]}

Figure 1 provides an overview of the development of the number of daily newspapers in the Netherlands since 1848 , when thirty papers existed. The number increased steadily until World War II after which period the market became more and more concentrated.

\section{[INSERT FIGURE 1 ABOUT HERE]}

In 1869 the market encounters an explosive increase as the Dutch government repeals the special tax system for newspapers, known as 'Dagbladzegel' ( see e.g. Hemels (1969a, b)). The abolition of this tax system stimulated economic activity for the newspapers' publishing companies. The costs for a publishing company to produce a newspaper decreased enormously with the abolition

decision of the government. According to Schneider and Hemels (1979) in some cases the 
production costs for existing newspapers decreased with fifty per cent in that year. This percentage shock did not only provide an economic incentive to increase the circulation of the incumbent newspapers, it also boosted the potential profits and consequently survival probabilities for the incumbents as well as for potential entrants.

A similar evolutional pattern is shown for the four regional markets in Figure 1. The Western and, although less so, the Northern market segments are most pronounced. The large differences in the numbers of newpaper titles among the national regions may be explained by the fact that the Western region has the highest population density and economic growth relative to the other regions in the Netherlands. The correlation between the regional density evolutions of the Western and Northern markets is 0.92 , whereas the correlation between the number of newspaper titles in the Eastern and Southern regions is only 0.35 , suggesting a weaker relation between the developments of the latter two regional markets.

A more precise overview of the dynamics of the Dutch newspaper market can be shown by looking at the annual aggregate number of newspaper births and deaths. Figure 2 illustrates a plot of the annual aggregate number of newspaper births from 1848 until 1997. The relative large number of newspaper births from 1869 reflects the effect of the change in the tax system. After the year 1900, the annual number of newspaper births gradually decreased. Immediately after the end of World War II, an inflow of new entrants occurred. The entry level shows a stabilized pattern after the war. The entry shock after the World War II is due to the fact that the market dramatically changed in the period 1940-1945 (see also Goedhart (1943)). After the war the underground newspapers prohibited by the pro-German government were legalized, while the newspapers which had collaborated with the pro-German government received a prohibition of appearance (cf. Schneider and Hemels (1979)). 


\section{[INSERT FIGURES 2 AND 3 ABOUT HERE]}

Immediately after World War II new opportunities for newspapers existed to conquer larger market segments and new clientele. These opportunities led to an increase of competitiveness in the market. More newspapers fought in the same market segments with a limited space for only a few newspapers. The development of competition reduced the survival chances of the potential entrants, and increased exit rates. The consequences of the increased competition on the Dutch market are shown in Figure 3, which presents the mortality pattern of the newspapers. The early period shows that the annual number of newspaper deaths had been influenced by the constitutional and economic changes. Between 1900 and 1940 the newspaper market was more or less stable, but after World War II the mortality of newspapers dramatically increased. On the aggregate, more newspapers exited the market.

To see whether the Dutch newspaper market experienced periods of high turbulence in which both entry and exit occur followed by periods in which hardly any turnover takes place, we computed correlations between the numbers of entrants and exiters over specific periods of time given in Table 4.1. For the whole sample period 1848-1997, the estimated correlation is significantly different from zero and equal to 0.39 . For the subperiods $1848-1900,1901-1939$, 1940-1945, and 1946-1997 the estimated correlations are $0.15,0.16,0.60$, and 0.29 respectively. With the exception of the postwar period, these correlations are not significantly different from zero. In conclusion, the Pearson correlations between entry and exit in the Dutch daily newspaper market are lower than those found in the industrial organization literature (see e.g. Sutton (1997)) for industry sectors. To the extent that we find positive correlation between entry and exit, it is mainly due to the political 'turbulences' during World War II.

Recent research on the evolution of the Dutch newspaper market concentrates on the 
explanation of the decrease of the number of newspaper titles, without taking into account the life cycle of the market. The figures show that a market life cycle for daily newspapers exists, a finding that is confirmed by Carroll (1987) in other countries. It seems likely to assume that the phase of the life cycle the newspaper market is in significantly affects an individual newspaper's expected lifetime. This being the case, the interpretation of expected survival rates must be done with care. For example, estimation of the liabilities of newness and adolescence depends crucially on the phase of the market, that should thus be taken into account.

Parameter estimates of the hazard functions

Table 4.2 presents the estimation results of the Cox's proportional hazard model and of the survivor functions being characterized by their respective distributions of duration. In general, one should recognize that the estimates of the proportional hazard model have opposite signs compared to those of corresponding variables of the survivor functions. In the Cox's proportional hazard model a positive sign of a parametric estimate can be interpreted as follows. If the corresponding variable increases, ceteris paribus, the hazard rate will increase also. This means that the conditional exit probability of a daily newspaper from the market, given that the newspaper has appeared for a specific period, increases if the value of an explanatory variable increases. In the case of survivor functions a positive sign indicates that an increase in the variable corresponds with an increased survival rate.

[INSERT TABLE 4.2 ABOUT HERE] 
As illustrated in the previous part of this section, the evolution of the daily newspaper market shows a turning point around the World War II. It is therefore interesting to test whether the developments in the number of newspaper titles before and after the break have a contrary effect on the hazard rate and survival rate of newspapers in the Netherlands. Dens 1 represents the pre-World War II number of incumbent newspapers one year before the newspaper enters the market. The density one year before entrance proxies the effects the intensity of competition might have on the probability of survival. The estimates of Dens1 are negative for the survivor functions. This indicates that in the period before the war a higher density the year before entry corresponds with a shorter expected lifetime. The estimates of Dens 2 are positive for the survivor function. This implies that the larger number of incumbent newspapers the year preceding entry the higher the market density and therefore the longer the expected endurance in the market. During the second phase of the newspaper market cycle entering has become more difficult, even though the number of newspaper titles has decreased.

The variables Diff3 and Diff4 have been created to investigate the effects the market density has on the survival chances of newspapers before and after World War II. Diff3 is defined as the difference between the number of incumbent newspapers in the year that newspapers left the market and the initial number of 30 newspapers in 1848 before World War II. Diff4 is defined similarly as the difference between the density the year in which the newspaper exited the market and the 1945 density of 124 different newspaper titles ${ }^{5}$. The estimates of the variable Diff3 are significantly different from zero with a negative sign in all the survivor functions. An increase in the number of newspaper over time illustrates an increase in competitiveness among incumbents and entrants. Our results show that an increase in competition among newspapers reduce the

5 The variable Diff 3 contains zero and positive values, whereas the variable Diff4 contains zero and negative values. 
survival chances of newspapers before World War II. After the war the effect of competition on the survival chances continues. If fewer newspapers are in the market the probabilities to survive for the incumbents increase.

It is clear that, in general, newspapers which appeared after 1945 have different survival opportunities than newspapers which appeared before the war. We do not know yet what may have caused this development after 1945. But we can estimate the extent of the downward trend even without understanding the reasons why. To do so, we created a dummy variable, Found, that indicates if a newspaper was founded after 1945. The estimates are significantly different from zero in all models and indicate that the newspapers being founded after 1945 have a lower chance to survive, than the other newspaper in our dataset.

Figure 1 shows a breaking period rather than a breaking point during World War II. The political developments before, during and after the war created all kinds of market opportunities for incumbent and entering newspapers. As a result a relatively large number of new newspapers emerged right after the war ended. The variable In $W W 2$ respresents part of this political process, and its coefficient estimate can be interpreted as the impact on newspapers with high survival rates that were forced out of the market. At the end of the turmoil period new opportunities existed for potential entrants. The variable PastWW2 acts to mimic the effect on life expectancy rates during the boom, and its coefficient estimate illustrates that the survival rate (hazard rate) of the incumbents decreased (increased) as a response to the increased competition after World War II.

We have already mentioned that the Dutch newspaper market is dominated by the firstmovers. One-fifth of the 55 newspapers that exist in 1997 were published already before the liberalisation of the press freedom in 1848. The estimate of the variable Left indicates that the first-movers' advantage is insignificantly different from zero in the family of Gamma distributions. 
With the survivor function derived from the Gamma distribution for durations being the model that describes the data best, we conclude that even though it is remarkable that a relatively large proportion of newspapers remain in the market during the whole cycle that we investigate they do not play a dominant role in the explanation of survival rates.

To estimate the parameters of the Cox's proportional hazard model and the survival models we have used the Western market as benchmark, in other words the Region West is our reference region. The variable region in the model indicates if the survival chances in the three other market segments in The Netherlands differ from the market segment West. Our results show that the Dutch market segments did not demonstrate significant variabilities in survival chances of the newspapers. The parametric estimates of the regional variables were insignificantly different from zero.

According to Kiefer (1988) the exponential distribution is unlikely to be an adequate description of the data if the sample contains both very long and short durations, as in the data set we use in this paper. In our study we find that the Weibull distribution is almost similar to the exponential distribution. The Gamma distribution, with $\theta=0.3$, seems to be the most appropriate for explaining the lifetimes of daily newspapers in the Netherlands. This model illustrates that the hazard rates of a newspaper in the first few years of existence is high, and then will decrease gradually over time. Survival models corresponding with a normal or logistic distribution are found to be weaker than a Gamma model. Formally we did not test the two additional models against the Gamma model. But the difference between the values of the log-likelihood functions are sufficiently large so that the two alternative models are likely to be rejected in a formal nonnested LR test.

The models discussed here are based on the assumption of identical survival distributions across units. However, it is likely that newspapers are not homogeneous, but may differ in 
characteristics as well as orientation. Therefore, we have tested the validity of homogeneity across the newspapers in our study. We estimated survival functions that correspond with the Weibull or the exponential distribution conditional on an unobserved random variable with a Gamma distribution that represents heterogeneity. We find that the assumption of homogeneity across units cannot be rejected. The estimated parameter that corresponds with the unobserved heterogeneity is found to be insignificantly different from zero ${ }^{6}$.

Using a LR test, the Weibull hazard rate is strongly rejected in favour of the generalized Gamma model. Also, the estimated values for $\rho$ and $\theta$ for the Gamma model differ substantially from the values $\rho=1$ and $\theta=1$, indicating that the proportional hazard rate model is likely to be inappropriate. Hence, the estimates using Cox's proportional hazard model should be used with care. Fortunately, the estimates for $\beta$ using Cox's approach are found to be similar to those for the Gamma model, indicating robustness of these estimates with respect to the choice of the functional form of the (baseline) hazard rate.

The hazard rate based on the generalized Gamma density function evaluated at the means of the explanatory variables is shown in Figure 4. In Figure 5, we plot the hazard rates for the individual newspapers. The graph in Figure 4 exhibits strong negative duration dependence for duration up to ten years, a phenomenon known in the literature as liability of newness (see e.g. Brüderl et al. (1992) and Hannan and Freeman (1989)).

For longer duration, the hazard rate increases very gradually indicating some liability of aging. The hazard function is not monotonic, but U-shaped. We find a value of $\theta \rho<1(\theta \rho=0.76)$ with $\rho>1$ ( $\rho=2.54)$. These findings imply negative duration dependence during the early age and

\footnotetext{
${ }^{6}$ The hazard function for the Weibull distribution that include the Gamma distribution for heterogeneity can be expressed as $\mathrm{h}(\mathrm{t})=(\lambda \rho)(\lambda \mathrm{t})^{\rho-1} /\left(1+\delta(\lambda \mathrm{t})^{\rho}\right)$. If $\delta=0$, then the hazard function corresponds with the distribution model without heterogeneity. If, in addition, $\rho=1 \mathrm{~h}(\mathrm{t})$ becomes a proportional hazard function.
} 
an increasing exit probability when newspapers grow older (cf. Lancaster (1990)) ${ }^{7}$. For shorter durations our results are in accordance with Sutton's (1997) second regularity of the probability of survival which increases with the unit's lifetime.

A similar but less explicit shape of the hazard rate at the means of the explanatory variables is shown in Figure 5. The graph in Figure 5 also illustrates the heterogeneity between individual newspapers explained by the covariates included in the model.

It should be noticed that for the Weibull distribution we find a value of $\rho$ slightly smaller than one implying negative duration dependence. The value of $\rho$ is however not significantly different from one as the large sample t-value based on the estimates given in Table 4.2 for the hypothesis $\rho=1$ is -0.90 . The findings are fairly robust in the sense that for longer durations, the hazard rates based on the generalized Gamma and the Weibull distributions are in line with a constant hazard rate implied by the exponential distribution.

For the logistic and the normal distributions, the sign of the duration dependence depends on the values of the covariates. But as noticed above, these distributions fit the data less well than the exponential, the Weibull and the generalized Gamma distributions.

Finally, it is worthwhile to point out that the coefficient estimates for the regional dummy variables North, East and South, though insignificant, are all positive. This indicates that other things being equal newspapers published in these regions have a higher survival rate than newspapers published in the Western part of the country. Given that the national newspapers are mostly based in the Western part of the Netherlands, this finding suggests that regional newpapers have found a specialist's niche that offers shelter against heavy competition.The

\footnotetext{
${ }^{7}$ The minimum of the U-shaped curve is the turning point between liability of newness and liability of aging. Figure 4 , the minimum of the hazard function is at approximately 70 years, which is larger than the average age of newspapers in the data set (48 years). This is plausible since the hazard function shows the propensity of a T-years old newspaper to exit, whereas the mean of age is dominated by the density of relatively young newspapers that exit.
} 
finding is possibly the result of a dual structure of segmented markets for generalists and for specialists respectively (see e.g. Carroll (1987) and Witteloostuijn et al. (1996) for a dual market structure resulting from resource partitioning).

\section{5. $\quad$ Conclusions}

In this paper we present a descriptive analysis of the evolution of the market for daily newspapers in the Netherlands for the period 1848 through 1997. We estimate hazard and survivor functions to investigate how much survival probabilities depend on the state the market is in. Three important phases are considered: the pre-World War II phase of growth since 1848, the period of turmoil during the war, and the post war period of increased concentration from 1945 until 1997.

Our results show that the estimation of a hazard rate crucially depends on the state of the market. Among economic variables, the intensity of competition at the time entrance takes place is found to be a key variable explaining chances of survival. In the Netherlands the daily newspaper market has reached the state where the opportunities to successfully found a new newspaper are very low. For future research, we recommend to collect and use data which account for density dependence of survival rates. Of course, this recommendation also applies to event historical research in other industries. Moreover, we think that the development of a dynamic market theory, for example by extending life cycle theories as in Jovanovic and MacDonald (1994) and Klepper (1996), allowing for more than one technology or policy shock to explain the dynamics of the daily newspaper industry in the Netherlands, is needed to obtain a thorough understanding of the economics that underlie the phenomena studied in this paper. 
Table 4.1: The Foundation of Daily Newspapers in the Netherlands Through Time

\begin{tabular}{|l|c|c|c|c|c|c|}
\hline period & $<1848$ & $1848-$ & $1901-$ & $1940-$ & $>1945$ & aggregate \\
\hline still & 1900 & 1939 & 1945 & \\
\hline 1997 & 9 & 21 & 9 & 6 & 10 & 55 \\
\hline total & 30 & 118 & 42 & 42 & 29 & 261 \\
foundations & & & & & & \\
\hline correlations & - & 0.146 & 0.164 & 0.595 & 0.292 & 0.388 \\
entry/exit & & & & & & \\
\hline
\end{tabular}


Table 4.2: Parameter Estimates of the Hazard Model and Survival Functions

\begin{tabular}{|c|c|c|c|c|c|c|}
\hline & \multirow[t]{2}{*}{$\begin{array}{l}\text { Cox's prop. } \\
\text { haz. rate model }\end{array}$} & \multicolumn{5}{|c|}{$\begin{array}{l}\text { SURVIVAL FUNCTIONS CHARACTERIZED BY THE } \\
\text { FOLLOWING DISTRIBUTIONS }\end{array}$} \\
\hline & & Exponential & Weibull & Gamma & Logistic & Normal \\
\hline \multirow[t]{2}{*}{ Constant } & & $5.29770 *$ & $5.29520 *$ & $6.1914 *$ & $4.4195 *$ & $4.0382 *$ \\
\hline & & $(0.28396)$ & $(0.32025)$ & $(0.30976)$ & $(0.35684)$ & $(0.36139)$ \\
\hline \multirow[t]{2}{*}{ Dens 1} & $(0.0146 *$ & $-0.01130 *$ & $-0.01119 *$ & $-0.01376 *$ & -0.00518 & -0.00218 \\
\hline & $(0.00373)$ & $(0.00388)$ & $(0.00428)$ & $(0.00341)$ & $(0.00525)$ & $(0.00555)$ \\
\hline \multirow[t]{2}{*}{ Dens 2} & $-0.06972 *$ & $0.089636 *$ & $0.090977 *$ & $0.088711 *$ & $0.092436 *$ & $0.094205 *$ \\
\hline & $(0.019371)$ & $(0.0263)$ & $(0.028403)$ & $(0.0228)$ & $(0.032134)$ & $(0.031)$ \\
\hline \multirow[t]{2}{*}{ Diff 3} & $0.02836 *$ & $-0.02656 *$ & $-0.027146 *$ & $-0.02120 *$ & $-0.034502 *$ & -0.034321 \\
\hline & $(0.00311)$ & $(0.00254)$ & $(0.0028)$ & $(0.00218)$ & $(0.00388)$ & $(0.00407)$ \\
\hline \multirow[t]{2}{*}{ Diff 4} & $0.06997 *$ & $-0.0786 *$ & $-0.099318 *$ & $-0.09746 *$ & $-0.097659 *$ & $-0.10081 *$ \\
\hline & $(0.0159)$ & $(0.02192)$ & $(0.023498)$ & $(0.01953)$ & $(0.026724)$ & $(0.03272)$ \\
\hline \multirow[t]{2}{*}{ Found } & $12.813 *$ & $-15.977 *$ & $-16.159 *$ & $-16.135 *$ & $-15.576 *$ & $-15.478 *$ \\
\hline & $(2.4809)$ & $(3.3444)$ & $(3.6146)$ & $(2.9467)$ & $(4.0143)$ & $(5.0291)$ \\
\hline \multirow[t]{2}{*}{ Past WW2 } & $0.90363 *$ & $-0.75713 *$ & $-0.77688 *$ & $-0.57648 *$ & $-1.0823 *$ & $-1.1353 *$ \\
\hline & $(0.24549)$ & -0.26641 & -0.28727 & -0.2074 & -0.36775 & -0.40044 \\
\hline \multirow[t]{2}{*}{ In WW2 } & $-1.2852 *$ & $1.3249 *$ & $1.3547 *$ & $0.87471 *$ & $2.0344 *$ & $2.0475 *$ \\
\hline & $(0.26006)$ & $(0.29807)$ & $(0.32565)$ & $(0.26553)$ & $(0.35699)$ & $(0.39048)$ \\
\hline \multirow[t]{2}{*}{ Left } & $-0.00609^{+}$ & 0.006918 & 0.007163 & 0.003452 & $0.012052 *$ & $0.014008 *$ \\
\hline & $(0.00368)$ & $(0.00425)$ & $(0.00458)$ & $(0.00418)$ & $(0.00426)$ & $(0.0047)$ \\
\hline \multirow[t]{2}{*}{ North } & -0.07066 & 0.07678 & 0.076778 & 0.045236 & 0.043184 & 0.15905 \\
\hline & $(0.24618)$ & $(0.25517)$ & $(0.27538)$ & $(0.22373)$ & $(0.32936)$ & $(0.35559)$ \\
\hline \multirow[t]{2}{*}{ East } & -0.23568 & 0.21612 & 0.22677 & 0.11185 & 0.43738 & 0.53151 \\
\hline & $(0.19808)$ & $(0.23901)$ & $(0.25643)$ & $(0.19879)$ & $(0.293)$ & $(0.30729)$ \\
\hline \multirow[t]{2}{*}{ South } & -0.17094 & 0.21469 & 0.22302 & 0.08314 & 0.41524 & 0.48342 \\
\hline & $(0.21871)$ & $(0.25186)$ & $(0.27237)$ & $(0.203)$ & $(0.32677)$ & $(0.32894)$ \\
\hline \multirow[t]{2}{*}{$\sigma=1 / \rho$} & - & 1 & $1.0543 *$ & $0.39363 *$ & $0.85177 *$ & $1.5012 *$ \\
\hline & & & $(0.063508)$ & $(0.20051)$ & $(0.056194)$ & $(0.089031)$ \\
\hline \multirow[t]{2}{*}{$\theta$} & - & 1 & 1 & $0.30000+$ & & \\
\hline & & & & $(0.17801)$ & & \\
\hline $\begin{array}{l}\text { Log- } \\
\text { lik.hood }\end{array}$ & -936.2823 & -403.5172 & -403.1289 & -393.8644 & -418.2681 & -417.7979 \\
\hline
\end{tabular}

* significant at 5 per cent; ${ }^{+}$significant at 10 per cent; standard errors in parentheses. 


\section{REFERENCES}

Abbring, J.H. and J.C. van Ours (1994), "Selling News and Advertisement Space: The Economics of Dutch Newspapers”, De Economist 142, 151-170.

Audretsch, D.B. and T. Mahmood (1995), "New Firm Survival: New Results Using a Hazard Function", The Review of Economics and Statistics 87, 97-103.

Brüderl, J., P. Preisendörfer and R. Ziegler (1992), "Survival Chances of Newly Founded Business Organizations", American Sociological Review 57, 227-242.

Carroll, G.R. (1987), "Publish and Perish: The Organizational Ecology of Newspaper Industries", JAI Press Inc., Greenwich.

Carroll, G.R. and M.T. Hannan (1995), “Organizations in Industry: Strategy, Structure and Selection”, Oxford University Press, New York.

Cox, D. (1975), "Partial Likelihood”, Biometrika 62, 269-276.

Cuilenburg, van J.J., J. Kleinnijenhuis and J.A. Ridder (1988), “Concentratie en Persklimaat: Een Empirisch Onderzoek naar de Mogelijkheid van een Persbarometer", Politikologische Studies, Vrije Universiteit, Amsterdam.

Dunne, T., M.J. Roberts and L. Samuelson (1988), "Pattern of Firm Entry and Exit in U.S. Manufacturing Industries", Rand Journal of Economics 19, 495-515.

Emery, E. and M. Emery (1978), “The Press and America”,, Prentice Hall, Englewood Cliffs (NJ).

Geroski, P. (1991), “Market Dynamics and Entry”, Basil Blackwell, Oxford. 
Goedhart, H.A. (1943), "De Pers in Nederland", Departement van Volksvoorlichting en Kunsten, Amsterdam.

Hannan, M.T. and J.Freeman (1989), “Organizational Ecology”. Harvard University Press.

Hemels, J. (1969a), “Op de Bres voor de Pers: De Strijd voor de Klassieke Persvrijheid”, Van Gorcum \& Comp. N.V., Assen.

Hemels, J. (1969b), "Het Dagbladzegel in de Rariteitenkamer, 1869-1969", Nijgh \& Van Ditmar, Rotterdam.

Jovanovic, B. and G.M. MacDonald (1994), “The Life Cycle of a Competitive Industry”, Journal of Political Economy 102 (2), 322-347.

Kiefer, N.M. (1985), "Specification Diagnostics Based on Laguerre Alternatives for Econometric Models of Duration", Journal of Econometrics 28, 135-154.

Kiefer, N.M. (1988), "Economic Duration Data and Hazard Functions”, Journal of Economic Literature XXVI, 646-679.

Klepper, S. (1996), "Entry, Exit, Growth, and Innovation over the Product Life Cycle", American Economic Review 86, 562-583.

Lancaster, T. (1990), "The Econometric Analysis of Transition Data", Cambridge University Press, Cambridge.

Overhof, S. (1995), “De Krant in Zuid-Limburg”, Leiter-Nypels B.V., Maastricht.

Ridder, de J.A. (1984), "Persconcentratie in Nederland, Begripsvorming, Bepaling en Beschrijving", VU Uitgeverij, Amsterdam. 
Ros, van de B. (Red.) (1993), “Geschiedenis van de Christelijke Dagbladpers in Nederland”, Uitgeverij Kok, Kampen.

Schneider, M. and J. Hemels (1979), “De Nederlandse Krant 1618-1978: Van 'Nieuwstydinghe' tot Dagblad", Het Wereldvenster, Baarn.

Stacey, E.W. and G.A.Mihran (1965), "Parameter Estimation for a Generalized Gamma Distribution", Technometrics 7, 349-358.

Sutton, J. (1997), “Gibrat’s Legacy”, Journal of Economic Literature XXXV, 40-59.

Tammeling, B. (1988), "De Krant Bekeken: De Geschiedenis van de Dagbladen in Groningen en Drenthe", Nieuwsblad van het Noorden, Groningen.

Vermeulen, H. (1994), "De Maasbode: De Bewogen Geschiedenis van 'de Beste Courant van Nederland"', Waanders, Zwolle.

Witteloostuijn van A., C.A.J.J. Boone, A.Th.M. van Iterson, R.L. Olie and R. van Well (1996), "Van Courantier tot Strateeg: De rol van manager en hoofdredacteur in het krantenbedrijf', manuscript, Universiteit Maastricht. 
1 Acknowledgements. We thank Theo van de Klundert, Gerard Kuper, and Arjen van Witteloostuijn for constructive comments. Glenn Carroll is gratefully acknowledged for the valuable discussions we had and the suggestions he made that helped improving the paper substantially. Our thanks are due to Robert van Well, Christophe Boone and Arjen van Witteloostuijn for their willingness to use part of the data that they collected on the Dutch daily newspaper industry after 1950. Gerard Pfann acknowledges the financial support by means of the PIONIER research grant from the Netherlands Foundation of Scientific Research. 